Інноватика у вихованні. Випуск 11. Том 1. 2020.

УДК 371.8

DOI: $10.35619 /$ iiu.v1i11.280

Олексюк Оксана

кандидат педагогічних наук, доцент,

доцент кафедри педагогіки та інклюзивної освіти, керівник Науково-дослідного центру військово-патріотичного виховання Миколаївського національного університету імені В. О. Сухомлинського,

м. Миколаїв, Україна

ORCID: 0000-0002-5527-3861, e-mail: oleksjukoksana@ukr.net

\title{
ВІЙСЬКОВО-ПАТРІОТИЧНЕ ВИХОВАННЯ СТУДЕНТСЬКОЇ МОЛОДІ: 3 ДОСВІДУ ВПРОВАДЖЕННЯ
}

Анотація. У статті розглядається досвід упровадження завдань військовопатріотичного виховання студентської молоді у ході діяльності Науководослідного центру військово-патріотичного виховання Миколаївського національного університету імені В.О. Сухомлинського. В основі діяльності центру - ідеї В.О. Сухомлинського щодо патріотичного виховання молоді з урахуванням сучасних наукових розробок вітчизняних науковців. Схарактеризовано напрями роботи, за якими здійснюється діяльність фахівцями Науково-дослідного центру та творчою групою викладачів, а саме: науково-дослідницька, науково-інформаційна, науково-організаційна, науково-методична та організаційна. Наведено перелік методик дослідження патріотичної та військово-патріотичної спрямованості особистості студента. Представлений аналіз діяльності фахівців Науководослідного центру 3 проведення науково-практичних конференцій та виховних заходів військово-патріотичного спрямування із залученням студентів, викладачів та виховників громадських організацій. Висвітлена співпраця з громадськими ветеранськими організаціями, учасниками АТО/ООС, Координаційною радою 3 військово-патріотичного виховання при Миколаївській обласній державній адміністрації під час проведення Всеукраїнського семінару «Кузня Захисників України». У перспективі подальших розвідок заплановані виховні заходи для учнівської молоді, наукові розробки для виховників з військово-патріотичного спрямування.

Ключові слова: патріотичне виховання, військово-патріотичне виховання, студентська молодь, гібридна війна, методика «Хто Я?», виховний захід.

Постановка проблеми. Проблема військово-патріотичного виховання сучасної молоді, зокрема студентської, $є$ вкрай актуальною. Особливо вона загострилася останніми роками. Освітній процес в університетах передбачає як навчальну, так і виховну складову, що має забезпечити неперервний процес виховання особистості як свідомого громадянина, здатного зрозуміти та приймати цінності суспільства своєї країни, готовності стати на захист її суверенності. Політичні події, що відбулися на Сході країни 2015 року, продемонстрували певні недоліки в організації патріотичного виховання серед студентської молоді на Донбасі та в АР Крим. Тому, постала проблема, яка вимагає нагального вирішення, а саме - удосконалити систему національно-патріотичного виховання, особливо військово-патріотичного іiї напряму. 
Аналіз останніх досліджень 3 проблеми. Серед сучасних дослідників, які вивчають питання складових патріотичного виховання та громадянських якостей особистості - I. Бех, М. Боришевський, П. Вербицька, М. Свтух, І. Зязюн, П. Ігнатенко, В. Кремень, С. Максименко, А. Погрібний, Ю. Руденко, О. Савченко, О. Сухомлинська, К. Чорна, Л. Чупрій О. Шестопалюк, П. Щербань та ін. Достатньо дослідженим у сучасній педагогічній науці є національно-патріотичне виховання Ю. Бондаренко, М. Боришевський, О. Вишневський, Р. Захарченко, В. Кузь, Б. Цимбалістий, В. Янів, Я. Ярема, О. Ярмоленко) та військово-патріотичне виховання - М. Зубалій, В. Івашковський. Значний внесок у розробку теорії та практики виховання воїнів здійснили військові науковці Е. Афонін, С. Гречко, I. Колодій, В. Маслов, В. Мірошніченко, Ю. Семенов, Г. Темко. Проблему готовності учнівської молоді до служби у Збройних Силах України досліджував I. Томчук, технологію оцінки ефективності військово-патріотичного виховання призовної молоді - Г. П'янковський.

Слід зазначити, що більшість робіт присвячена вихованню учнівської молоді, оскільки вважається, що студент - це молода людина із сформованою системою цінностей, і виховувати іiї не має потреби. Але ж виховання - це цілеспрямований, неперервний і довготривалий у часі (людина виховується все своє життя) процес. Виховний вплив на студента здійснюється під час навчального процесу, позааудиторної діяльності, організації самостійної роботи студентів тощо. Тому викладач університету повинен усвідомлювати необхідність патріотичного виховання студентів і бути для них прикладом відданого ставлення до своєї країни, сумлінної відповідальної праці та творчої діяльності в усіх професійних сферах. Як тут не пригадати слова великого педагога Василя Сухомлинського, який зазначав «...громадянин виростає там, де $\epsilon$ почуття обов'язку перед людьми» (Сухомлинський, 1977, с.300),

Особливу увагу у виховному процесі Василь Сухомлинський приділяв такому методу виховання як приклад. Педагог підкреслював: «відкрийте його очі і серце на минуле й сьогодення свого народу так, щоб люди з їхніми радощами і бідами, 3 любов'ю до рідної землі та 3 ненавистю до іiі ворогів постали перед вашим вихованцем у живому втіленні, щоб, пізнаючи минуле, юний громадянин думав про сьогодення і майбутнє» (Сухомлинский, 1978, с. 23). Фахівці Науково-дослідного центру військово-патріотичного виховання Миколаївського національного університету ім. В. О. Сухомлинського у своїй роботі керуються виховними орієнтирами видатного педагога; при проведенні виховних заходів підкріплюють їx змістовну частину емоційними прикладами героїчних вчинків співвітчизників різних історичних епох і подій, а також сучасності.

Ольга Сухомлинська у статті «В. Сухомлинський про патріотизм: тести $\mathrm{i}$ контексти» (2016, с. 5-6), аналізуючи працю педагога «Щоб у серці жила Батьківщина» та його збірку «Родина в сердце», доходить висновку про глибокий зміст та грунтовне висвітлення ідеї патріотичного виховання у книзі «Родина в сердце», яка залишається актуальним засобом патріотичного виховання й нині.

Ідеї Василя Олександровича 3 патріотичного виховання лягли в основу діяльності Науково-дослідного центру 3 військово-патріотичного виховання Миколаївського національного університету імені В. О. Сухомлинського та набули свого розвитку з урахуванням подальших наукових досліджень українських вчених і сучасних реалій життя.

Приміром, не можна обійти увагою в роботі центру сучасний стан подій на Сході України та поняття «гібридна війна», яке наразі $\epsilon$ найактуальнішим поясненням проблем, що виникли. Робота з військово-патріотичного виховання 
потребує тлумачення цього поняття, обговорення його змістовної складової у наукових тезах, статтях, диспутах, круглих столах. У монографії Горбуліної Національного інституту стратегічних досліджень (2017 р.) детально проаналізоване поняття світової гібридної війни, яке розуміють як воєнні дії, що здійснюють шляхом поєднання мілітарних, квазімілітарних, дипломатичних, інформаційних, економічних та інших засобів з метою досягнення стратегічних політичних цілей (Горбуліна та ін., 2017, с. 19).

Мета статті - презентувати досвід Науково-дослідного центру військовопатріотичного виховання Миколаївського національного університету імені В. О. Сухомлинського з упровадження різних форм військово-патріотичного виховання студентської молоді.

Виклад основного матеріалу дослідження. Виходячи із зазначеного вище, та 3 метою реалізації завдань військово-патріотичного виховання студентської молоді у лютому 2019 року при Миколаївському національному університеті імені В. О. Сухомлинського був створений Науково-дослідний центр військовопатріотичного виховання. До складу центру входять керівник та фахівець, які здійснюють координацію роботи творчої групи науковців університету за індивідуальними напрямами з виконання наукових досліджень $з$ теми «Військовопатріотичне виховання студентської молоді в умовах освітнього простору університету», яка входить до тематичного плану наукових досліджень НАПН України з 2015 року (керівник теми - ректор університету, акад. В. Д. Будак).

Фахівці Науково-дослідного центру (далі - НДЦ) з військово-патріотичного виховання та творча група викладачів здійснюють свою діяльність за різними напрямами роботи: науково-дослідницька, науково-інформаційна, науковоорганізаційна, науково-методична та організаційна.

При цьому будь-який напрям грунтується на результатах проведеної діагностики, позаяк для ефективності діяльності необхідно враховувати вихідний рівень національно-патріотичної та військово-патріотичної вихованості студентської молоді й т. п.

Фахівцями НДЦ спільно з фахівцями Психологічної служби університету проводяться дослідження за різними методиками, наприклад: «Збройні сили України. Які вони?», «Хто Я?». Аналіз отриманих результатів дає можливість встановити кластерний розподіл відповідей студентів. За першою методикою «Збройні сили України. Які вони?» можна встановити характерні ознаки, якими наділяють студенти військовослужбовців. За другою методикою «Хто Я?» студентів можна розподілити за рольовим призначенням, які вони собі присвоїли. Важливим аспектом для нашого дослідження $є$ наявність ролей, які пов'язані 3 патріотичною темою, державою, суспільством тощо.

Щорічно в університеті проводиться Всеукраїнська науково-практична конференція «Наука. Студентство. Сучасність» для молодих вчених та здобувачів вищої освіти. Фахівці центру є членами оргкомітету конференції та відповідають за іiї проведення. У 2019 р. конференція мала назву «Патріотичне і громадянське виховання студентської молоді: проблеми, традиції, стратегічні орієнтири» (15-16 травня). У 2020 р. конференція з теми «Військово-патріотичне виховання молоді: традиції, досвід, проблеми та перспективи» (14-15 травня) проводилася онлайн. Крім пленарного та секційних засідань, у програмі конференції передбачені круглі столи, диспути, тренінги та творчі майстерні. Наприклад, тематика круглих столів: «Роль викладача вищої школи у підготовці патріотично налаштованого вчителя», «Військово-патріотичне виховання і підготовка молоді до служби в ЗСУ», «Наша істинна національність - Людина», «Роль особистості педагога у патріотичному 
вихованні дітей», «Виховання у сучасної молоді якостей лідера-патріота на прикладах героїчних подвигів учасників воєнних подій», «Роль педагога у патріотичному вихованні майбутнього покоління» та диспутів: «Національнопатріотичне виховання: аргументи за і проти...», «Хто такий лідер-патріот», «Патріот чи маргінал...», «Бути чи не бути поколінню патріотів в Україні?» цікавить студентів й мотивує до активної участі в обговоренні окреслених проблем.

Всеукраїнська науково-практична конференція «Патріотичне виховання особистості в умовах сучасного освітнього простору: досвід, тенденції та проблеми» (5-6 грудня 2019 р.) була організована з метою залучення викладачів до обговорення актуальних питань патріотичного виховання дітей та молоді, 3'ясування основних теоретичних засад формування особистості, обміну досвідом, координації змісту науково-дослідної роботи. Було проведено змістовне пленарне та секційні засідання, у роботі яких, крім науково-педагогічних працівників взяли участь i директори закладів освіти, вихователі-практики, колишні військовослужбовці, керівники громадських організацій. Традиційним уже стало проведення круглих столів «Вічні цінності», «Виховання патріотичних почуттів сучасної молоді на прикладі трагічних подій XX ст.», ділової гри «Лідер-патріот це ...», диспуту «Психологічний підхід до формування національно-патріотичних цінностей у студентської молоді», творчої майстерні «Створення мультфільмів за текстами віршів патріотичного змісту».

Окремим напрямом роботи НДЦ можна вважати військово-патріотичне виховання через змістовну складову виховних заходів. У кожному виховному заході, організованому фахівцями НДЦ, прослідковується військово-патріотична складова. До організації заходів долучаються співробітники, викладачі та студенти університету, що допомагає впроваджувати ідеї військово-патріотичного виховання у середовище університету.

Наприклад, захід «Полум’я пам'яті» був організований разом 3 Науковою бібліотекою МНУ імені В. О. Сухомлинського і проводився в читальній залі бібліотеки. Захід, присвячений 75-ій річниці визволення території Миколаївської області від нацистських окупантів, а також вшануванню пам'яті почесного громадянина міста Миколаєва, полковника, професора, завідувача кафедри педагогіки університету, учасника бойових дій в роки Другої світової війни Грицая Юрія Олександровича. Присутні мали змогу прослухати вірші та пісні на військову тематику, почути спогади колег про великого педагога, відвідати мінікінозал і переглянути короткометражний фільм «Юрій Олександрович - у пам’яті назавжди!», відвідати віртуальну екскурсію «Музей бойової слави iм. Ю. О. Грицая». Співробітники бібліотеки презентували бібліографічний покажчик «Юрій Олександрович Грицай».

Літературно-музична композиція «Героїв країна - моя Україна!» була присвячена сучасним воїнам-захисникам нашої Батьківщини, всім тим, хто стоїть на сторожі безпеки та зміцнення Української держави. Студенти вшанували хвилиною мовчання загиблих воїнів, виконували пісні, читали поезії про силу та мужність воїнів-захисників, презентували відеоролик «Що для мене означає війна». Завершився захід спільним виконанням пісні «Хай буде мир в Україні!».

Глибокий емоційний вплив справив на студентів та викладачів університету виховний захід «Гірчить Чорнобиль крізь роки», присвячений трагічним подіям квітня 1986 року. Розповіді про героїчні вчинки пожежників та військовослужбовців викликали переживання та сльози у присутніх. Добірка відеоматеріалів сприяла зануренню в атмосферу заходу. Демонструвалися кадри 
подій на Чорнобильській АЕС, евакуації населення, спогади ліквідаторів та інформація про наслідки радіації для всього людства та планети в цілому. Під час виховної години звучали вірші, авторські поезії, лунали пісні у виконанні творчого центру «Естетика». Традиційно, як і на кожному заході, загиблих вшанували хвилиною мовчання. Найбільш емоційним моментом був виступ зі спогадами доньки полковника хімічної частини Міністерства оборони, який з перших часів катастрофи знаходився в зоні підвищеного ризику. По завершенню заходу всі присутні на стенді «Дзвони Чорнобиля» залишили відгуки про трагедію, яка сталася 34 роки тому, і від якої й донині потерпають жителі нашої країни.

Запрошені мали змогу переглянути книжкову виставку, ознайомитися 3 віртуальною виставкою «Пам'ятники жертвам та загиблим Чорнобиля», які знаходяться на території України та інших держав. Необхідно зазначити, що такий захід, хоча й не відображає суто воєнних подій сучасності, проте акцентує увагу на вчинках співвітчизників, які готові надати допомогу населенню країни у скрутну хвилину, демонструє готовність громадян-патріотів захищати країну, ризикуючи своїм здоров'ям та життям.

Ще одним напрямом роботи Науково-дослідного центру 3 військовопатріотичного виховання $\epsilon$ співпраця 3 громадськими ветеранськими організаціями, учасниками АТО/ООС, Координаційною радою 3 військовопатріотичного виховання при Миколаївській обласній державній адміністрації. Результати такої співпраці були відображені під час проведення Всеукраїнського семінару «Кузня Захисників України» (1-3 листопада 2019 р.).

Всі виховні заходи, проведені НДЦ, висвітлюються та популяризуються через Instagram та сторінку в соціальній мережі Facebook «Науково-дослідний центр військово-патріотичного виховання МНУ імені В. О. Сухомлинського», яка наразі має більше, ніж 200 прихильників. Саме в соціальній мережі здійснюється й анонсінформування про перспективи діяльності НМЦ і заплановані заходи.

Висновки і перспективи подальших розвідок. Отже, науково-дослідна робота фахівців Науково-дослідного центру з військово-патріотичного виховання, викладачів і студентів університету, які є членами творчої групи з проблемної теми, проводиться за тематичним планом наукових досліджень і має вагомі результати, які висвітлюються в наукових статтях, тезах та обговорюються на конференціях. Змістовною в межах наукової теми є виховна робота, що здійснюється під керівництвом та за безпосередньої участі в іiі організації фахівців центру та студентів університету. Перспективи подальших розвідок вбачаємо в аналізі запланованих виховних заходів для молоді, в наукових розробках для виховників 3 військово-патріотичного спрямування.

\section{СПИСОК ВИКОРИСТАНИХ ДЖЕРЕЛ}

Сухомлинський, В. (1977). Вибрані твори. В 5-ти т. Т. 5. Київ: «Рад. школа». $639 \mathrm{c}$.

Сухомлинский, В. (1978). Родина в сердиее. Москва: Мол. гвардия. 175 с.

Сухомлинська, О. (2016). В. Сухомлинський про патріотизм: тексти і контексти Педагогічний пошук. № 4. C. 4-7. URL: http://nbuv.gov.ua/UJRN/pedp_2016_4_2. [Дата звернення 06 березня 2020].

Горбуліна, В. (2017). Світова гібридна війна: украӥнський фронт : монографія. Київ : НІСД. 496 с. 
Інноватика у вихованні. Випуск 11. Том 1. 2020.

\title{
REFERENCES
}

Sukhomlynskyi, V. (1977). Vybrani tvory. [Selected Works]. V 5-ty t. T. 5. Statti. Kyiv, "Rad. Shkola". 639 s.

Sukhomlynskyi, V. (1978). Rodina v serdtse [Motherland in the Heart]. Moskva: Mol. gvardiya. $175 \mathrm{~s}$.

Sukhomlynska, O. (2016). V. Sukhomlynskyi pro patriotyzm: teksty i konteksty [V. Sukhomlinsky on Patriotism: Texts and Contexts]. Pedahohichnyi poshuk. No 4. S. 4-7. URL: http://nbuv.gov.ua/UJRN/pedp_2016_4_2. [Data zvernennia 06 bereznia 2020].

Horbulina, V. (2017). Svitova hibrydna viina: ukrainskyi front : monohrafiia [World Hybrid War: Ukrainian Front: monograph]. Kyiv : NISD. 496 s.

\section{MILITARY-PATRIOTIC EDUCATION OF STUDENTS: EXPERIENCE OF ITS IMPLEMENTATION}

\begin{abstract}
Oksana Oleksiuk
Candidate of Pedagogical Sciences, Associate Professor, Associate Professor at the Department of Pedagogy and Inclusive Education, the Head of Scientific-Research Center of Military and Patriotic Education of V.O.

Sukhomlynskyi Mykolaiv National University,

Mykolayiv, Ukraine

ORCID: 0000-0002-5527-3861

e-mail: oleksjukoksana@ukr.net
\end{abstract}

\begin{abstract}
The article deals with the experience of the implementation the tasks of military-patriotic education of students as a part of the activities of the Research Center for Military-Patriotic Education at the V.O. Sukhomlynskyi Mykolaiv National University. The purpose of the article is to show the experience of the Scientific-Research Center of Military-Patriotic Education in the implementing various forms of militarypatriotic education at the university.

The activity of the center is based on the ideas of V.O. Sukhomlinsky on the patriotic education of youth, taking into account modern scientific developments of Ukrainian scientists. The directions of work in which activities are carried out by specialists of the Research Center and a creative group of teachers, in particular: research, research, information, scientific and organizational, scientific and methodological and organizational, were described.

The list of some methods of study of patriotic and military-patriotic orientation of the student's personality is given. The analysis of the activity of specialists of the Research center for conducting scientific and practical conferences and educational actions of the military-patriotic orientation with involvement of students, teachers and leaders of public organizations is given. The Research center's cooperation with public veteran organizations, ATO / OOS participants, and the Coordinating Council for MilitaryPatriotic Education at the Mykolaiv regional state administration in the process of the AllUkrainian seminar "Forge of Defenders of Ukraine" was characterized

The activities of the Research Center are popularized through Instagram and the Facebook page "Research Center for Military-Patriotic Education of V. O. Sukhomlynskyi Mykolaiv National University".
\end{abstract}

Key words: patriotic education, military-patriotic education, student youth, hybrid war, "Who Am I?", educative event. 